\title{
Miss Brasil Gay Juiz de
} Fora: os trajes típicos e suas mulheres imaginadas de 2017 a 2019

Miss Brasil Gay Juiz de Fora: ethnic costumes and their imagined women from 2017 to 2019 


\section{Paulo de Oliveira Rodrigues Junior ${ }^{1}$}

ORCID: https://orcid.org/0000-0003-3779-1101

[resumo] 0 Miss Brasil Gay é um concurso que elege o mais belo transformista gay do país desde 1977, em Juiz de Fora (MG). 0 evento é dividido em duas fases principais e este trabalho busca compreender a etapa do traje típico, correspondente à representação dos aspectos culturais dos estados brasileiros pelas misses. Delimitando as análises entre os anos de 2017 a 2019, realizamos um levantamento dos vídeos, fotografias e reportagens referentes ao Miss Brasil Gay que circularam nas plataformas oficiais do evento e também no jornal eletrônico Acessa. Exploramos o material a partir das teorias de gênero junto de uma bibliografia relacionada ao traje típico, ao figurino e à fantasia. Baseando-se no que foi exibido na passarela, classificamos os trajes típicos em três categorias principais (figurino, fantasias e trajes étnicos), entendendo que, na competição, as identidades regionais nem sempre se encontram em primeiro plano, e sim na construção de uma mulher exuberante. Abordamos, também, o papel dos estilistas dentro do concurso, uma vez que seus imaginários e modos de fazer definem muitas vezes o que será apresentado, tramando narrativas imagéticas que transitam tanto pelos aspectos legitimados como tradicionais quanto com imagens globalizadas do ser mulher.

\section{[palavras-chave] Miss Brasil Gay. Homossexualidade. Traje típico.}

[abstract] Miss Brasil Gay is a beauty contest that elects the most gorgeous female illusionist in the country since 1977, in Juiz de Fora. The event is divided into two main phases and this article seeks to understand the "ethnic costume" stage, representing the cultural aspects of Brazilian states by the misses. Outlining the analyzes between the years 2017 to 2019, we conducted a survey of the videos, photographs and reports referring to Miss Brasil Gay that circulated on the official platforms of the event, and also in the electronic newspaper "Acessa". We explored the material from the theories of gender with a bibliography related to typical costume, costumes and fantasy. Based on what was showed on the catwalk, we classified "ethnic costumes" into three main categories (costume design, fantasy clothing and ethnic/national costumes), understanding that at the competition, regional identities it is not always firsthand shown, it is indeed focused in the construction of an exuberant woman. Then, we also observe the role of stylists within Miss Brasil Gay, since their imaginary and know-how often defines what will be presented by the misses, plotting imagery narratives that moves through both traditional characteristics and images of a globalized woman.

[keywords] Miss Brazil Gay. Homosexuality. Ethnic costumes.

Recebido em: 05-10-2020

Aprovado em: 05-12-2020

\footnotetext{
${ }^{1}$ Doutorando e Mestre pelo Programa de Pós-Graduação em Artes, Cultura e Linguagens da Universidade Fe-
} deral de Juiz de Fora. E-mail: paulo.orjr@gmail.com. Lattes: http://lattes.cnpq.br/7297495830275293. 


\section{Introdução}

O desfile de traje típico no Miss Brasil Gay compõe uma das etapas do concurso para se chegar ao trono de mais belo transformista gay do Brasil. 0 objetivo deste trabalho é entender as negociações que emergem nas montações desses trajes, em que aspectos étnicos e feminilidades entram em diálogo para conceber aparências de mulheres elegantes, disparando a seguinte pergunta: o que essas misses querem (a)parecer? Partindo do entendimento de que montação é uma gíria LGBTQ+ usada no intuito de aparentar uma figura feminina, as relações entre as narrativas que retrataram características históricas, econômicas, culturais, religiosas e artísticas de um estado, atravessadas pelas ideias de uma feminilidade e um glamour, ajudam a inventar o que é ser uma miss gay.

O Miss Brasil Gay teve início em 1977, na cidade de Juiz de Fora, em Minas Gerais, e foi idealizado pelo cabeleireiro Chiquinho Mota para arrecadar fundos para a escola de samba Juventude Imperial, constituindo-se, também, como uma paródia do tradicional Miss Brasil, no Maracanãzinho, no Rio de Janeiro, frequentado por homossexuais e travestis entre as décadas de 1950 e 1970 (GREEN, 2000). Acontecendo até os dias atuais e dividido em duas fases principais - os desfiles de traje típico e de traje de gala -, o concurso se estabeleceu como um dos mais importantes do país na arte do transformismo. Seu regulamento dispõe que: pessoas transexuais, travestis e participantes com intervenções cirúrgicas ou hormonizadas estão impossibilitadas de participar; cada estado federativo deverá, a partir de uma delegação oficial, enviar sua candidata; a concorrente deverá ter entre 18 e 38 anos; e fica vetada a participação por mais de três vezes. As normas, no entanto, nem sempre são cumpridas.

0 traje típico expõe uma série de aparências que chamam a atenção pelo seu teor carnavalesco, um aspecto que contribuiu para o diálogo entre o concurso e a cidade. Os jornais e a própria organização identificaram o Miss Brasil Gay com essa temática, já que, desde a década de 1990, Juiz de Fora vinha perdendo as grandes produções de seus carnavais (TRIBUNA DA TARDE, 1991). Mas essa justificativa é insuficiente; os laços não se deram somente por isso. As imagens que circularam por esses desfiles de beleza e a própria ideia de suspensão/inversão do cotidiano que existe na tradição carnavalesca mostram uma relação mais complexa entre o Miss Brasil Gay, os trajes típicos e o carnaval.

Como nas estruturas do carnaval, no Miss Brasil Gay essas misses escapam do cotidiano, invertendo suas posições sociais generificadas; se fora das fronteiras do Miss Brasil Gay elas são homens, cis, gays, travestis ou mulheres trans marginalizadas na sociedade, na competição, elas se transformam em mulheres elegantes do mundo do entretenimento, invocando signos daquilo que é entendido como glamour, reordenando o tempo e o espaço nesse processo de autocriação que trama também com a cultura de massa (OCHOA, 2014). A dinâmica do evento se aproxima novamente do ritual do carnaval, quando a matéria-prima da construção imagética é o próprio dia a dia (DA MATTA, 1973). Um deslocamento que, se 
anteriormente eram imagens de desejo consumidas a partir das telas da mídia ou das vivências marginalizadas, encontradas em espaços destinados a LGBTQs, agora se localizam materializadas pelos trajes típicos que as transformam nesses objetos de deleite.

Querer (a)parecer provoca sonoridades/definições de aparecer/parecer. Enquanto parecer tem como sinônimo aparentar ou imitar, também se relaciona a um entendimento, um juízo sobre algo, cujos significados mostram-se intimamente ligados ao transformismo, que no Miss Brasil Gay é sintetizar aquilo que se entende como mulher e etnicidade. Já aparecer remete à ideia de emergir, existir - e por meio de todo o material e da forma do traje, as misses se projetam na passarela radiantes, sempre provocando emoções múltiplas, tramando com a ideia de carnaval e corpo que Da Matta (1973) delineia sobre o recato ser substituído pela abertura do corpo ao grotesco. No concurso, esse movimento abre mão das aparências coerentes da heterossexualidade do cotidiano para a exuberância de uma feminilidade espetacular da cultura de massa, que expõe os processos pelos quais esses corpos assumem narrativas de modernidade e periferia (OCHOA, 2014).

Essas misses carregam consigo imagens femininas presentes nas mídias, parodiando-as e as reatualizando. A paródia é captada como instrumento de fuga do cotidiano, mas é também uma indicação da ficção dos gêneros e das sexualidades, categorias construídas durante o tempo e cristalizadas na repetição de atos estilísticos (BUTLER, 2003). Se essas misses buscaram esses símbolos femininos dentro da cultura de massa foi porque a verdade contada sobre essas feminilidades é legitimada por tecnologias que teceram e deram inteligibilidade por meio de representações inseridas em um interesse ideológico do sistema vigente (DE LAURETIS, 1994; SCOTT, 1995). Nessa direção, como realça Oluwakemi Balogun (2012), concursos de beleza, especialmente os de abrangência nacional, oferecem a possibilidade de pesquisar como esses ideais de beleza de gênero desempenham um papel importante na construção da imagem de nação/região tangível na produção de identidade nacional/regional generificada.

Glamour aqui advém da feminilidade reverberada pela indústria cinematográfica hollywoodiana entre as décadas de 1920 e 1950. Como aponta Carol Dyhouse (2010), ele é encarnado em elementos que constroem essa mulher fabulosa: o brilho dos diamantes, as peles grossas, as silhuetas curvilíneas, as flores exóticas e os lábios vermelhos. A autora destaca, nas décadas de 1920 a 1940, o uso de penas e plumas como signos de exotismo glamoroso que projetaram o movimento dessas mulheres nas telas do cinema, ampliando sua extravagância e sedimentando tais elementos como uma qualidade do glamour (DYHOUSE, 2010). A escolha desses materiais não se mostra inocente quando aproximamos os trajes típicos e o vestuário hollywoodiano desse período. Esses recursos simbólicos disponíveis e presenciados no Miss Brasil Gay são colocados como uma estratégia de expansão de si por um vestuário camp, tanto das misses como das atrizes de Hollywood que, na predileção pelo exagero das formas e das feminilidades, transformam essas imagens de si em subterfúgios para fuga do cotidiano, aliando-se, assim, com a própria ideia e a imagem do carnaval (SONTAG, 2020). Logo, o glamour concebe-se como um modo de agência, em que as faustosas 
montações possibilitaram às misses desafiarem a heteronormatividade, escaparem do habitual e irromperem com a invisibilidade na sociedade juiz-forana, embora certas obediências às normas de gênero e classe permanecessem respeitadas (SOLIVA, 2016).

0 termo típico nem sempre apareceu de fato nas montações. Se o típico é um modo de valorizar as riquezas e os valores regionais de cada estado, as narrativas contadas por meio desses trajes não se relacionam com seu ente federativo necessariamente (CABALLERO PIZA, 2018). Ao longo do concurso, os trajes típicos parecem mais projetar uma figura feminina deslumbrante do que realçar aspectos de uma cultura.

Em 2007, o decreto municipal n. 9275/07 considerou o Miss Brasil Gay como patrimônio imaterial de Juiz de Fora, demonstrando sua relevância cultural e econômica. Alguns estudos concordam em atribuir ao Miss Brasil Gay uma importância na história e na política LGBTQ+ (RODRIGUES, 2009; RODRIGUES 2014; KELMER, 2016). As contribuições deste trabalho visam ampliar a importância das aparências dentro do concurso, compreendendo que os trajes típicos são fundamentais para entender as construções históricas das identidades LGBTQ+, colaborando para a escrita de um movimento LGBTQ+ mais plural e descentralizado das metrópoles.

A análise delimitou-se às edições de 2017 a 2019, transitando entre fotos e vídeos das páginas oficiais do concurso nas redes Instagram, Youtube, Facebook e no site www. missbrasilgay.com.br, como também no jornal eletrônico Acessa. Levantamos informações sobre 71 trajes típicos. Em relação ao ano de 2018, alguns dados ficaram incompletos por não haver acompanhamento on-line, e as entrevistas no site Acessa não foram suficientes para complementar tais lacunas. Os nomes das misses, os estados representados, o tema da roupa e algumas informações sobre o material e a forma do figurino e o estilista que o assinou possibilitaram categorizá-los e entendê-los melhor dentro do contexto do concurso.

Em um primeiro momento, os trajes foram classificados em três categorias a partir das narrativas, dos materiais, das formas inseridas nas peças e, quando possível, da performance da miss, abordando aquilo que convergiu e destoou dentro do concurso, na tentativa de observarmos como se dão as aparências das misses, percebendo que certos atos se cristalizaram como a imagem de um traje típico de uma miss gay, articulando gênero e etnicidade.

Abordamos, ainda, como os estilistas conceberam tais produções, buscando compreender os processos narrativos das aparências dos trajes típicos. Entender a região e a trajetória profissional viabilizou captar os rastros da sua imaginação, questionando sobre o que cada um evidenciou: o global, ligado principalmente à cultura de massa/moda; ou o tradicional, que traz elementos étnicos do lugar representado.

\section{Figurino, fantasia ou traje típico?}

Apresentado à plateia o estado retratado, temas, materiais e as assinaturas dos estilistas compõem o ideal de traje típico no Miss Brasil Gay. A música de fundo e o modo como a miss desfila constituíram-se uma equação a compor uma performance de miss. Há uma 
negociação entre as narrativas e os materiais empregados, uma vez que emular uma mulher glamorosa é um dos objetivos centrais do evento. Não é exceção nas descrições números inflados de pedrarias.

A partir do levantamento dos trajes, compreendemos existir uma complexidade na hora de construir e classificar o traje como típico. As formas, as narrativas e os materiais nem sempre colaboraram para a ideia de etnicidade, fugindo para outros territórios, seja do carnaval, da cultura de massa ou até mesmo imagens que circulam em espaços LGBTQ+. Em relação à construção material do traje típico, a recorrência de alguns elementos transforma-se em axiomas para conceber uma miss, compondo uma montação em cima de uma feminilidade que exagere na opulência, determinando uma via de mão dupla: o vestuário constrói aquele sujeito em miss, mas a miss também se agencia por meio da indumentária, projetando-se a uma audiência e fazendo com que sua existência seja demarcada nesse espaço, manipulando, pelo consumo, significados relacionados ao poder que elas detêm financeira ou simbolicamente (MILLER, 2013; VEBLEN, 1974). Nesse sentido, Aureliano Lopes (2012) discorre que nesses tipos de concurso, além de um ideal branco de beleza feminina, existe uma necessidade de construir uma imagem que paute o estabelecimento de uma ordem que difunda a ideia de requinte, a fim de afastar o estigma dos sujeitos (GIACOMINI, 2006).

Strass, penas, brilhos, cristais e componentes metálicos foram elementos localizados em todos os trajes típicos. Não quer dizer que uma criação teria todos esses materiais empregados, mas pelo menos um deles sempre está presente, simbolizando tanto a ideia de glamour como as trocas com o modo de fazer carnavalesco.

As formas sugeriram a existência de categorias dentro dessa etapa. Se, em um primeiro momento, pensamos que as narrativas sobre os temas escolhidos pudessem compor primariamente os trajes típicos, consideramos também os estilistas a partir de suas vivências. Contudo, definiremos essas formas associadas às narrativas, que muitas vezes destoaram da ideia de uma cultura popular local e do traje regional.

\section{Das narrativas}

Nos 71 trajes típicos pesquisados, encontramos uma maior recorrência de narrativas sobre lendas e religiosidades, ocupando 25,36\% do total. Essa categoria envolve religiões afro-brasileiras, indígenas e cristãs, mitologias e lendas urbanas - como exemplo, o traje típico da Miss Minas Gerais em 2018, criado por Anderson Martthus, que trouxe a deusa do ouro; ou a lenda de Ana Jansen, contada pela Miss Maranhão em 2019 com a confecção de Ribas Azevedo.

Em segundo lugar, a fauna e a flora constituem 22,54\% das narrativas. Evidenciar os animais, as florestas ou os biomas foram modos de trazer alguns aspectos naturais dos estados. A Miss Mato Grosso do Sul, em 2017, levou o pantanal como símbolo; no mesmo ano, a Miss Paraíba exaltou o sol, já que João Pessoa é a primeira cidade a começar o dia no país. 
Os temas relacionados à economia (classe trabalhadora, principal produto interno etc.) aparecem com 14,08\%. Em 2017, a Miss Rio Grande do Norte, com um traje assinado por Bob Uchoa e Junior Toledo, homenageou a extração do sal no estado, vestindo-se de musa do sal. Já a Miss São Paulo, em 2019, usou um traje assinado por Michelly X que prestigiava os motoqueiros paulistanos. Acontecimentos e personagens históricos $(12,68 \%)$, festas típicas $(11,26 \%)$ e lugares turísticos $(9,86 \%)$ também se fizeram presentes nos enredos dos trajes típicos, como também clubes futebolísticos $(1,40 \%)$, bandeiras políticas $(1,40 \%)$ e híbridos (1,40\%).

Observamos que, em um primeiro momento, algumas narrativas foram inventadas para o concurso, isto é, não são histórias sedimentadas na cultura popular ou características verídicas dos estados. Se nos atentarmos para as primeiras posições, percebemos que esses temas manipulam as histórias contadas, enfatizando os aspectos sobre feminilidades. É o caso do uso da figura de deusas, musas e virgens; até mesmo para as características naturais ou econômicas, há uma metonímia que contribui para feminilizar esses sujeitos, outorgando qualidades femininas de gênero e sexualidade (NOLETO, 2014). Testemunhamos na atmosfera carnavalesca do Miss Brasil Gay mais uma experiência e a fantasia livre do que de fato um discurso exaustivo sobre as narrativas (BAHKTIN, 2008).

\section{Das montações}

Locomotiva criativa do imaginário das misses e dos estilistas, o carnaval não influencia apenas a aparência do vestuário, mas também o modo de fazer dos trajes. A maioria dos estilistas trabalha em ateliês que produzem para diversos carnavais brasileiros, do Norte ao Sudeste do país. Além dos materiais, as formas deram o tom carnavalesco aos trajes típicos e configuraram categorias no desfile.

Contrastando os trajes típicos em si, constatamos quatro categorias principais nessa etapa: fantasias carnavalescas, fantasias em geral, figurinos e trajes étnicos. Entendemos que analisar de modo enrijecido tais conceitos seria apagar os matizes que cada traje típico traz em sua individualidade; não obstante, encontramos nessa metodologia uma forma de entender as aparências dentro do Miss Brasil Gay.

\section{Fantasias}

As fantasias classificam-se em de carnaval e em geral. Usualmente, elas mantiveram um diálogo com o tempo/espaço carnavalesco, sendo que essas trocas ultrapassaram o envolvimento histórico do concurso e dos próprios estilistas. 0 carnavalesco no Miss Brasil Gay foi uma forma de organização que teve como objetivo suspender a vida cotidiana e propor confabulações em que as misses e os estilistas experimentaram outras existências. 
A categoria fantasia é a que mais apareceu nesses últimos três anos, entendendo que na fantasia existe a possibilidade de diversas interpretações, sejam ideais e/ou estereótipo da cultura. Da Matta (1973) aponta que o termo fantasia relaciona-se também ao imaginário e aos seus subuniversos de significação. A representação do exótico nas fantasias carnavalescas apareceu como aquilo que se difere da cultura euro-estadunidense na direção de uma ideia de cultura abaixo dos trópicos, ligando-se ao indígena e ao folclore misturados à imagem espetacular do carnaval, às representações vinculadas ao estado federativo e à cultura de massa.

0 erotismo foi articulado pelas aparências carnavalescas e pelas feminilidades em todas as fantasias, não se relacionando às festividades do carnaval no Brasil, quando mulheres podem se exibir seminuas - pois a conduta de uma miss não lhe permite esse comportamento público. No Miss Brasil Gay, as narrativas que envolvem a Virgem Maria foram recorrentemente enaltecidas, cristalizando a imagem de uma mulher virginal, ou seja, a burguesa. 0 erótico aqui aponta para um subterfúgio do olhar e do prazer que, conciliado com as feminilidades da cultura de massa, transformam as misses em imagens para o deleite do olhar (DA MATTA, 1973; MULVEY, 1983).

\section{Fantasias carnavalescas}

O conceito de fantasia poderia não ser suficiente para as interpretações, desse modo recorremos ao termo fantasia de carnaval, que contribui para compreendermos as especificidades dessas criações que envolvem texturas, formas, materiais e símbolos reconhecíveis (OLIVEIRA, 2014). As fantasias de carnaval remetem profundamente às aparências das festividades carnavalescas e outras festas populares que utilizam dessa aura, como escolas de samba, Festival de Parintins, carnavais nordestinos, etc. As associações entre essas fantasias se dão por causa do constante uso de esplendores (forma), penas e plumagem (materiais), elementos recorrentes nessas festividades e que repousam no imaginário social como algo folclórico e até mesmo exótico dentro da própria cultura brasileira. A utilização do carnavalesco mostra-se um recurso para definir um traje típico que é constantemente colocado como símbolo da cultura brasileira; trata-se de uma articulação entre o conhecimento processual dos estilistas e as imagens carnavalescas que foram introjetadas nas diversas identidades regionais e, também, no próprio ethos brasileiro. No exemplo da figura 1, a imagem da imperatriz - que, junto das rainhas de bateria, no carnaval, reverberam pela televisão o que é ser mulher. Ainda que os trajes típicos/fantasias carnavalescas no Miss Brasil Gay tenham suas modificações graças aos truques da roupa para compor o corpo feminino, as mulheres do carnaval são apropriadas pelas misses, evidenciando uma feminilidade transnacional, que é produzida atendendo a ideia de nação dentro dos circuitos de trocas em massa (OCHOA, 2014). 
FIGURA 1 - RENATTA TERUEL, IMPERATRIZ DA GAVIÕES DA FIEL, USANDO UM TRAJE COMPOSTO PELO ESPLENDOR (2017)

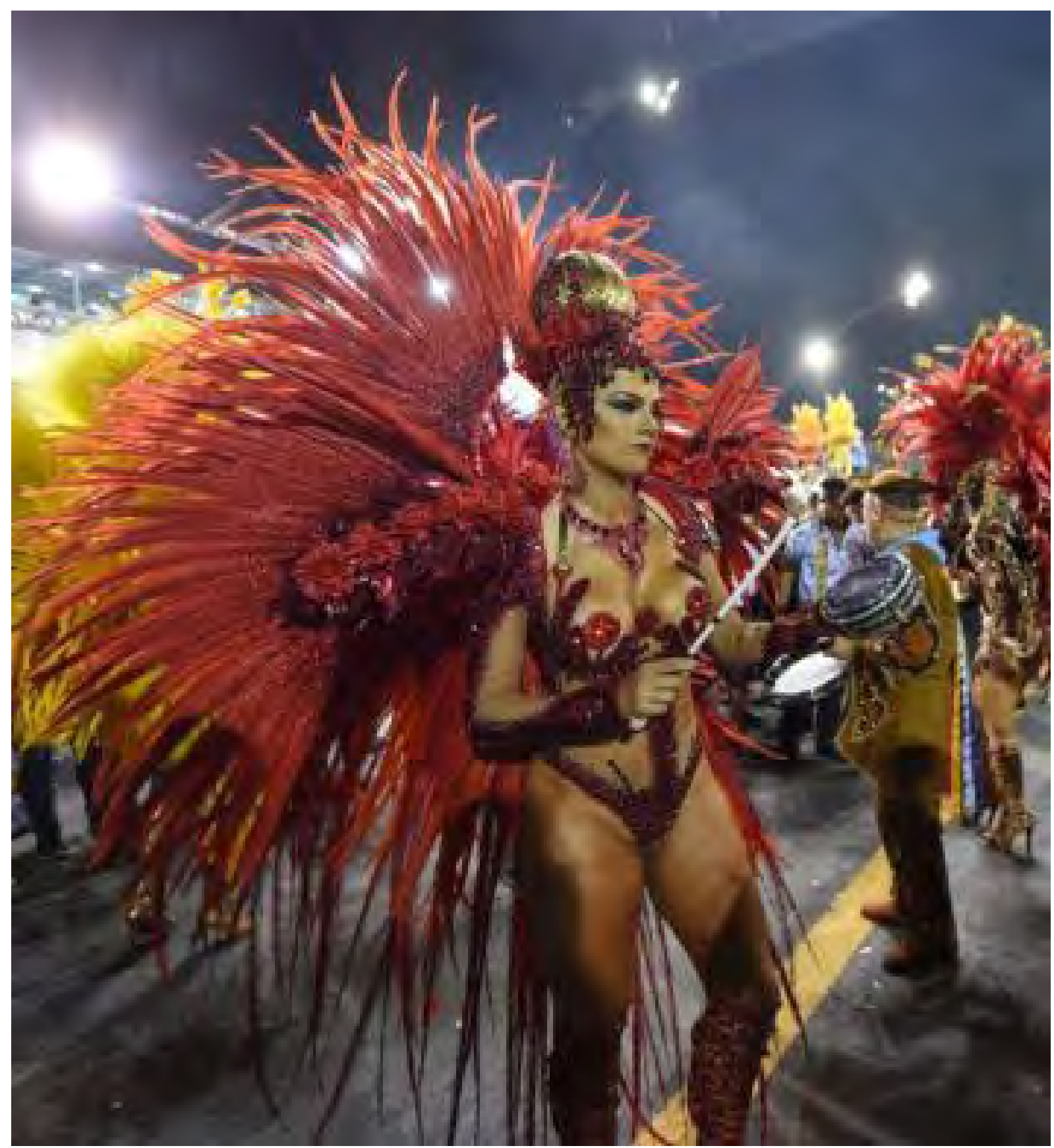

FONTE: FERREIRA, Dalton. Após briga em ensaio técnico, Gaviões da Fiel afasta Tati Minerato e Renatta Teruel. São Paulo: G1, 2018. Foto: Flavio Moraes. 
FIGURA 2 - AS MISSES AMAZONAS, ESPÍRITO SANTO E PARÁ NO DESFILE DE TRAJE TÍPICO (2017)
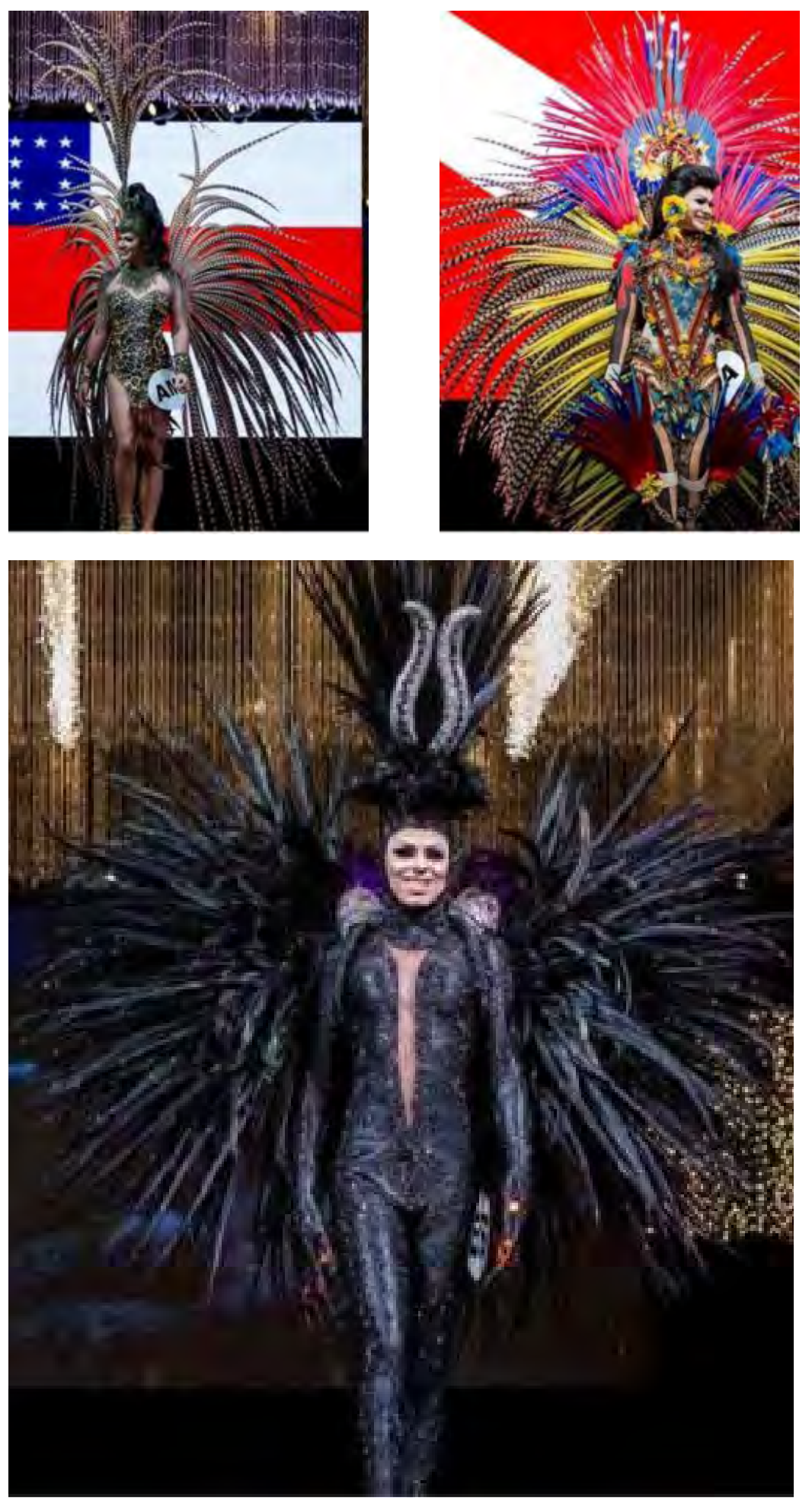

FONTE: Miss Brasil Gay 2017. Juiz de Fora: Miss Brasil Gay, 2017. Foto: Filmar. 
Na figura 2, as misses usaram as penas para se aproximarem da aparência indígena, o que interpretamos como um artifício para colocar o que é considerado exótico na passarela. Exótico denota "não originário do país em que ocorre; que não é nativo ou indígena; estrangeiro e que é esquisito, excêntrico, extravagante" (EXóTICO, 2020). As denominações nativo, indígena, estrangeiro e extravagante desempenharam, a partir do traje típico, um interessante jogo quando forma, matéria e narrativa operam simultaneamente, revelando as complexidades que perfizeram esses trajes que sintetizam uma identidade local. Na maioria das vezes, apesar de os estilistas invocarem aspectos folclóricos, étnicos ou indígenas, todas as concepções foram atualizadas e não passaram de uma idealização dos traços culturais, distanciando da realidade sobre determinadas narrativas e partindo para um olhar que exotizou determinados grupos, principalmente culturas indígenas. Essas articulações de aspectos racialmente indígenas, negros ou mestiços podem retratar uma tentativa, como aponta Rafael Noleto, de tramar "certo poder libidinal nos corpos e nas performances das candidatas [...] sustentado pela ideia de 'mistura', simbolicamente representada tanto pela ambiguidade das identidades de gênero e de sexualidade" (NOLETO, 2014, p. 3314), isto é, a ideia construída de brasilidade/regionalidade remetida à miscigenação.

0 desfile do traje típico da Miss Amazonas em 2017 (figura 2, à esquerda) consistiu na fauna amazônica "vista com requinte e glamour" (MISS BRASIL GAY, 2017). Apresentou-se, ainda, como uma homenagem à rainha do folclore, o Boi Bumbá e o Festival de Parintins. Tudo isso materializado em seda, faisões reais, rabo de galo e strass, criado pelo ateliê Kaleb Aguiar. Ainda que o estilista seja domiciliado no do Amazonas, na própria descrição do traje pelos apresentadores, o modo como foi interpretada a cultura amazonense baseou-se em uma concepção de requinte e glamour. Afastando-se de uma aparência que ilustrasse aspectos locais e repousando no conceito de selvagem e carnavalização, simbolizados pela estampa de onça e pelo esplendor, o estilista utilizou de artifícios já consolidados e estereotipados sobre o Amazonas - que, em grande parte, nem mesmo se conectavam com a narrativa escolhida. Kaleb Aguiar elegeu um contexto visual que favorecesse a ideia de glamour e carnaval, deixando em segundo plano uma identidade local/regional amazonense, o que coloca uma questão: se o que é produzido por sujeitos LGBTQ+ do Amazonas e toda sua miscelânea de referências não são considerados a identidade de um povo para além do que é legitimado, o que poderia compor essas identidades fora de uma ordem heterossexual?

O traje típico da Miss Espírito Santo (figura 2, ao centro) contou uma lenda desconhecida, que se assemelha ao conto das sereias, de uma deusa que foi aprisionada entre os ouriços do mar na Baía de Vitória, usando de luzes para enfeitiçar marujos e os aprisionar. Com penas e cristais e a assinatura do ateliê de Flávio Rafalski, a miss desfilou ao som da composição $O$ Fortuna, uma cantata criada pelo compositor alemão Carl Orff inspirada no poema homônimo Carmina Burana, dedicado à deusa romana. Culturalmente nada se entrelaçou ao estado representado. A trilha sonora, a mesma da Miss Espírito Santo 2013, também não comunicou uma identidade capixaba, posto que nem sempre existe uma preocupação com as características do estado, mas, sim, o impacto audiovisual que toda a montação oferece como discurso imagético, recorrendo ao exótico da atmosfera carnavalesca, alinhavando ao exagero de pedrarias confabulações com o carnaval, o glamour e as feminilidades de massa. 
Em caminho oposto, a Miss Pará (figura 2, à direita) optou por trazer no seu traje uma narrativa mais específica do seu estado. Diferentemente de muitas misses que representaram regiões nortistas a partir da criação de estilistas sudestinos, que preferem utilizar imagens estereotipadas do Norte, a Miss Pará juntou-se ao estilista amazonense Rodolfo Gomes e revelou a história da matriarca das Icamiabas, que foram mulheres indígenas guerreiras em terras sul-americanas, dando origem ao mito das amazonas. Seu traje típico usou formas e materiais que recriam peças usadas nos festivais encontrados no Pará, aproximando-se, por exemplo, do Festival de Tribos Indígenas de Juruti, deixando perceptível que os modos de criação mudam conforme a posição geográfica do estilista.

\section{FIGURA 3 - À ESQUERDA, A MISS PARÁ VESTIDA PELO ESTILISTA RODOLFO GOMES. À DIREITA, DESTAQUE MUNDURUKU NO FESTIVAL DE TRIBOS INDÍGENAS DE JURUTI (2017)}

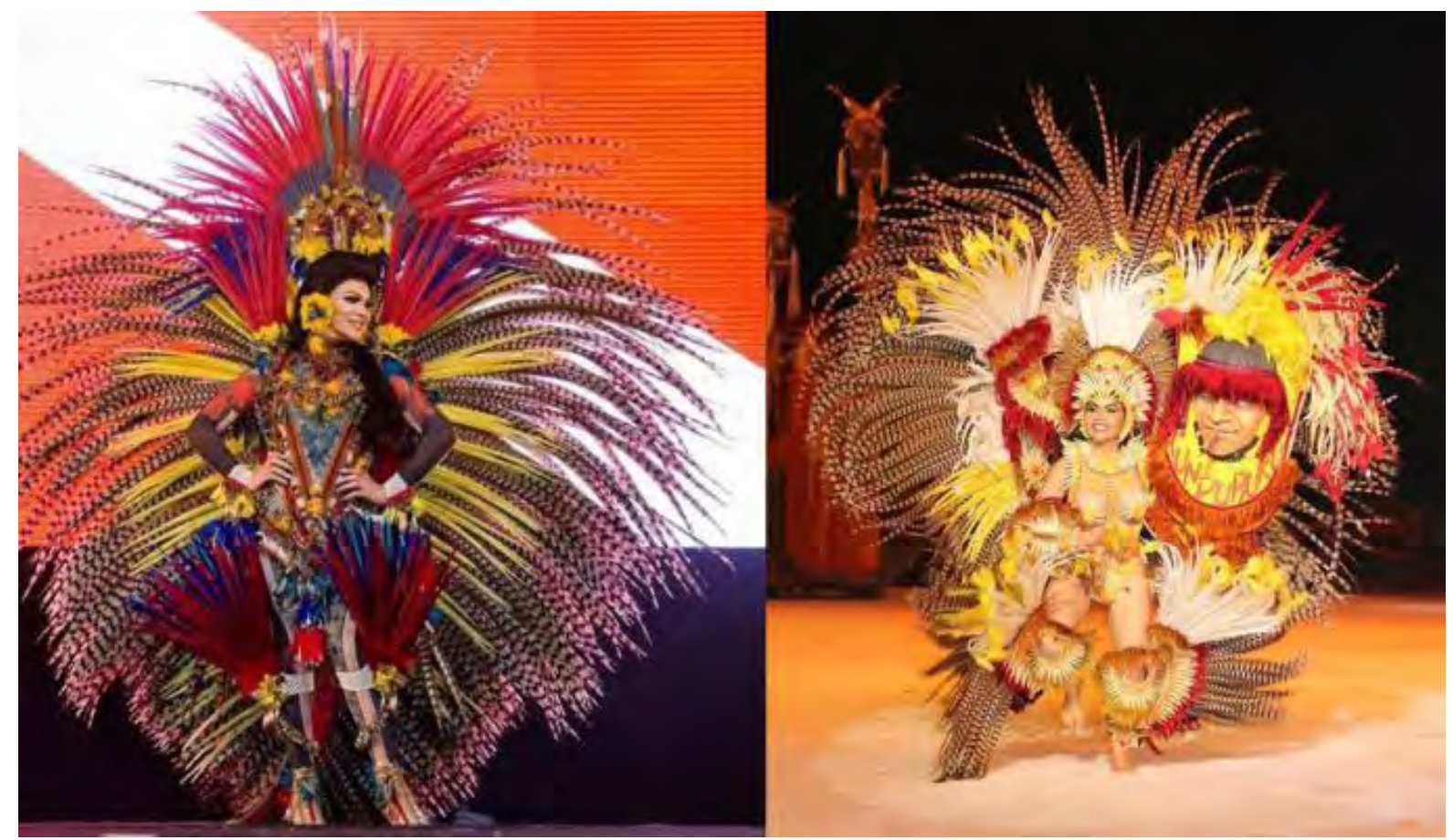

FONTE: Miss Brasil Gay 2017. Juiz de Fora: Miss Brasil Gay, 2017. Foto: Filmar/ CARNEIRO, Jeso. 24a edição do Festival das Tribos de Juruti inicia amanhã com a Festa dos Visitantes. Santarém: Jeso Carneiro, 2018.

\section{Fantasias em geral}

Uma das características da festa carnavalesca é vestir-se de algo ou alguém - e, nesse sentido, as fantasias em geral não fugiram da comemoração. Contudo, elas se distanciaram das aparências estritamente ligadas à festividade, abrindo espaço para confabular com outras imagens, como arquiteturas, animais, tecnologia e feminilidades midiáticas e religiosas. Houve uma diferenciação maior das formas e dos materiais (brilho, strass, cristais e metalizados), unindo-as como fantasias, mas não necessariamente às escolas de samba, aos festivais do Norte, etc. 
O uso de esplendores não se repete na maioria das fantasias em geral, embora certas formas sejam semelhantes a eles. Nessa categoria, geralmente, a performance corporal é a reprodução de um andar mais calmo, sem grandes gesticulações, parodiando uma tradicional miss.

FIGURA 4 - A MISS MINAS GERAIS, GUIGA BARBIERI, COM SEU TRAJE TÍPICO (2017)

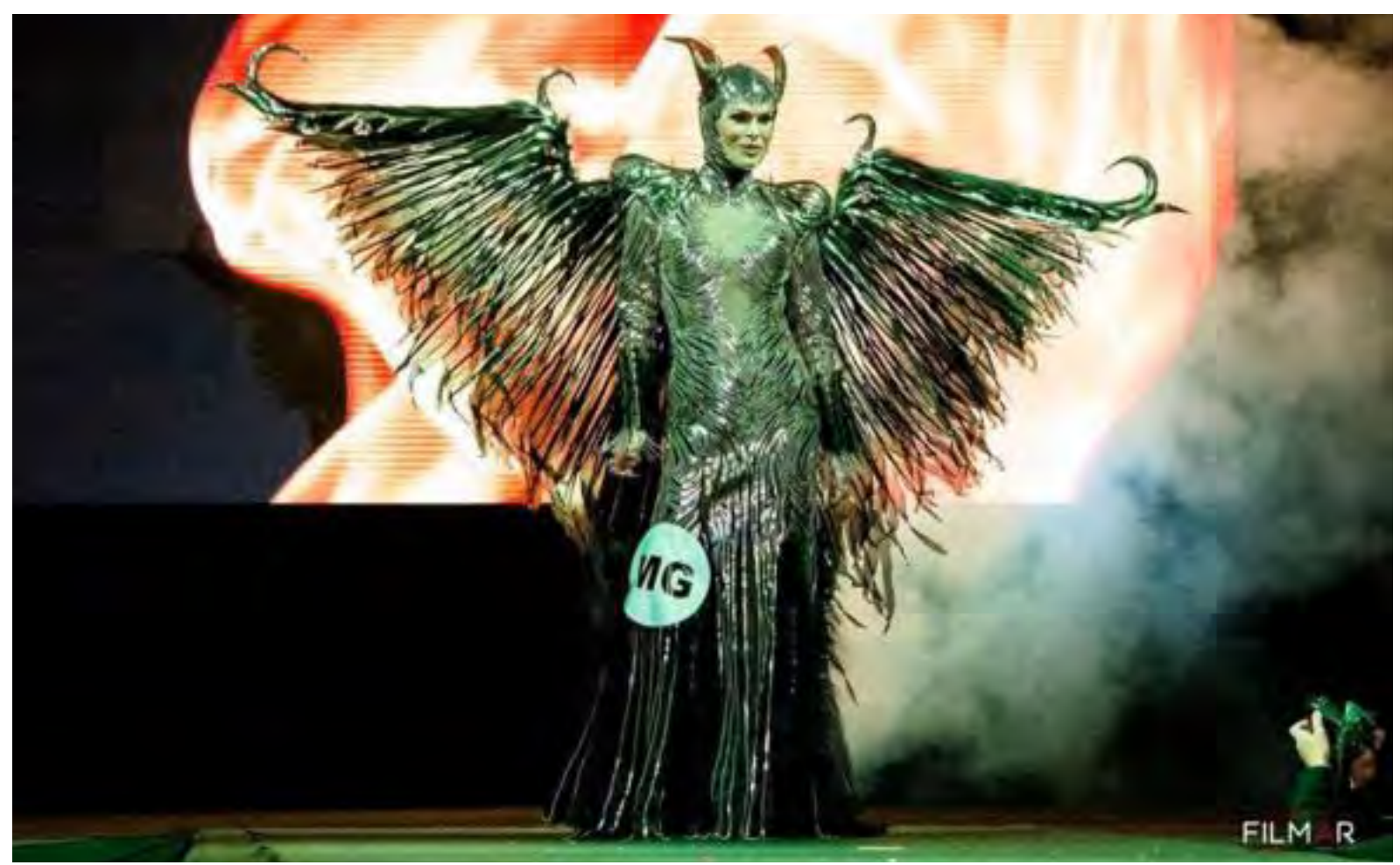

FONTE: Miss Brasil Gay 2017. Juiz de Fora. Miss Brasil Gay, 2017. Foto: Filmar.

Na figura 4, a então Miss Minas Gerais Guiga Barbieri (eleita a Miss Brasil Gay 2017) ostentou uma criação do estilista Henrique Filho inspirada no Capeta do Vilarinho, uma lenda de Belo Horizonte que fala sobre o capeta que se vestiu de gente para participar dos bailes do Vilarinho - a história em si foi uma estratégia de marketing de Francisco Filizzola, dono do Vilarinho. 0 carnaval encontra-se presente na forma de apresentação do enredo e no desenvolvimento na passarela, que ocorre como em um desfile na Sapucaí, no qual é preciso, a partir dos trajes, criar alegorias para as histórias de cada estado. Outro acessório que se aproxima do tom carnavalesco é a própria asa, que remeteu ao esplendor.

As vivências LGBTQ+ foram alinhavadas por Guiga Barbieri, ultrapassando um concurso de beleza tradicional. A trilha sonora bate-estaca, como são conhecidas as músicas eletrônicas de boates LGBTQ+, e a ideia de inferninhos (lugares pequenos, com música alta e cujas noites costumam ser frequentadas por sujeitos marginalizados) dão um toque bicha. Por meio do glamour, as misses reconfiguraram o lazer cotidiano na passarela. Ademais, a fantasia de Guiga remeteu à personagem Malévola, dos estúdios Disney, interpretada por Angelina Jolie na versão lançada em 2014, tornando-se uma referência de fantasia nos blocos carnavalescos. 
Pela fantasia, essas misses não tentam se afirmar em uma verdade identitária, mas transitar por territórios que o cotidiano não as permite experimentar, não somente como mulheres, mas mulheres espetaculares disseminadas pelas mídias (BAKHTIN, 2008). A partir de uma fantasia como de Guiga Barbieri, para além das paródias de gênero de modo geral, reconhecemos as possíveis mulheres que elas confabularam nesses trajes típicos, tanto da cultura de massa como das próprias figuras femininas LGBTQ+.

\section{Figurinos}

A categoria figurino não é identificada dentro de uma fronteira rigorosa na qual cada traje não pode se conceber de outra forma. Englobamos figurino a partir da criação do estilista (o traje) e a maneira pela qual a miss se apresentou na passarela, uma vez que entendemos aqui que o figurino está estritamente ligado à performance, pois a miss se encarregou de criar um diálogo entre a sua personagem mulher e uma outra - ou melhor, ela não somente estampou algum aspecto do estado, como também deu uma mobilização cênica a todo o conjunto.

Samuel Abrantes, ao pensar sobre os atos de criação do figurinista, colocou que é possível conferir uma "dimensão mítica aos objetos e às formas manipuladas no espetáculo. São escolhas que inspiram a produção do gesto do ator [...]" (ABRANTES, 2017, p. 8). Em outras palavras, os artifícios usados para constituir o figurino são manipulados na performance das misses, disparando uma funcionalidade simbólica para quem as assiste.

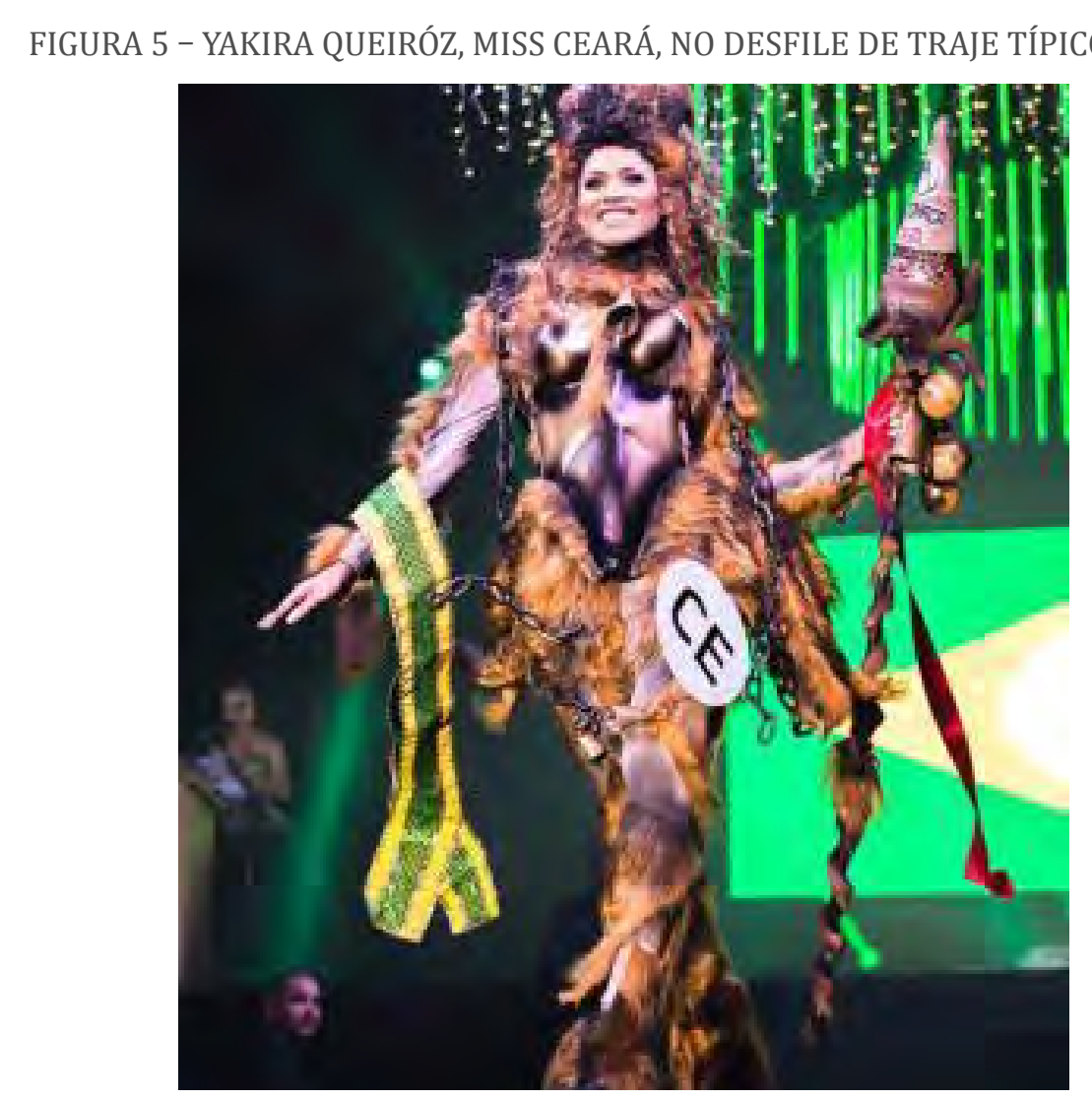

FONTE: ANTUNES, Rafael. Yakira Queiroz representante do Ceará vence a 38ª Edição do Miss Brasil Gay. Juiz de Fora: G1, 2018. Foto: Luciano Lima Jr. 
O desfile de traje típico de 2018 da Miss Ceará (figura 5) apresentou um figurino assinado por Ciro Alencar, o bode Ioiô - uma figura folclórica cearense que costumava perambular pelas ruas com intelectuais e boêmios nos anos de 1920; como forma de protestar contra a política local, Ioiô foi eleito como vereador em Fortaleza. Diferentemente de algumas concorrentes que andam com passos contidos, como uma miss tradicional, a performance da Miss Ceará foi mais teatralizada, não exibindo apenas o traje, mas construindo uma personagem bode guerreiro, uma miss guerreira. Como trilha sonora, o samba Um amô, da escola de samba carioca Paraíso do Tuiutí, colocou a miss não só para desfilar, mas para sambar na passarela. Os adereços nesse tipo de traje possuíam uma função para além de representar o estado: materializar a narrativa da miss, transformando a realidade na cena. Com um enredo secundário e de exceção, a Miss Ceará também apresentou um tom politizado, já que o traje representava um apelo à livre expressão, além de uma homenagem à cidade de Redenção, que foi o primeiro município brasileiro a libertar os escravizados (referência que aparece nas correntes do figurino). Ioiô seria um símbolo de irreverência, com seu cetro construindo essa imagem de poder e encantamento. O figurino teve "a função de objeto na cena, seja no corpo do ator ou funcionando como adereço de cena" (VIANA, 2017, p. 14).

\section{Trajes étnicos}

Refletindo sobre as roupas no contexto do Miss Universo, Joahnne Eicher e Barbara Sumberg (1999) propõem que o traje típico/nacional pode ser entendido como uma marca de etnicidade, usado para comunicar a identidade de um grupo ou de um indivíduo e suas interações. Embora partam do mesmo princípio, no national costume do Miss Universo é preciso sintetizar uma identidade nacional, enquanto o traje étnico no Miss Brasil Gay define uma identidade regional; apesar disso, na apresentação de algumas misses presenciamos o recurso de uma imagem nacional consolidada para representar o regionalismo, como, por exemplo, as fantasias carnavalescas. Para Stuart Hall (2006), tanto as culturas nacionais quanto as regionais são composições não apenas de instituições culturais, "mas também de símbolos e representações. Uma cultura nacional é um 'discurso' [...]" (HALL, 2006). Ou seja, é uma "comunidade imaginada” na qual recorrer a esses símbolos e representações nada mais é do que reiterar uma ficção social sobre determinado espaço/tempo (ANDERSON, 2008, p. 32).

0 traje nacional e a cultura nacional, via de regra, constituem-se de uma visão romântica a partir do folclore, exemplificado pelos campesinatos (EARLE, 2008, p. 164). Lou Taylor (2004) destaca que o processo de invenção de um traje nacional abrange uma romantização e uma apropriação dos "estilos rurais e de ícones utópicos de lutas democráticas e de restauração da cultura nacional” (TAYLOR, 2004, p. 213-214). Na imagem abaixo (figura 6), a Miss Sergipe vestiu-se de cangaceira, homenageando as mulheres sergipanas, uma criação assinada por Ferrulla Muniz que ajuda a compreender como foi concebido o traje étnico dentro do concurso. 
FIGURA 6 - MISS SERGIPE HOMENAGEANDO AS MULHERES SERGIPANAS (2018)

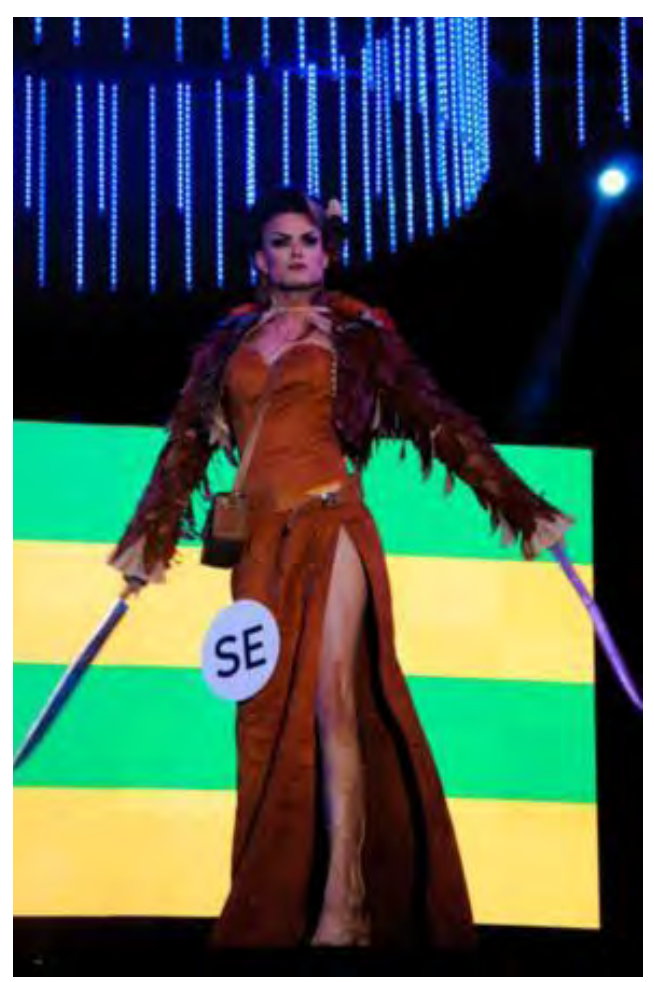

FONTE: Miss Brasil Gay. Juiz de Fora: Miss Brasil Gay, 2018.

FIGURA 7 - MARIA BONITA, QUE, APESAR DE BAIANA, FOI UM ÍCONE DO CANGAÇO SERGIPANO

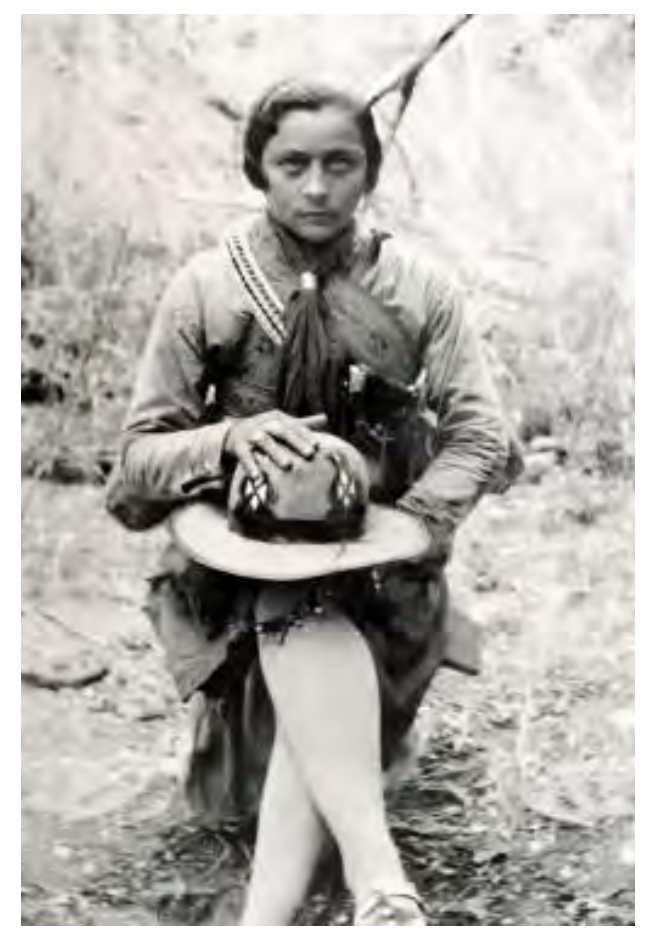

FONTE: Maria Bonita. Wikipédia. Foto: Benjamin Abrahão Botto (1936). 
O traje invoca a figura de Maria Bonita (figura 7), a cangaceira mais famosa da história do cangaço, esposa de Lampião. Com adereços de couro, as cores e o tecido empregados também aludiram a esse material, muito usado nos acessórios dos cangaceiros e que se transformou igualmente em um símbolo econômico de alguns estados nordestinos. Atrelando-se aos cangaceiros qualidades como violência, banditismo e desordem, a busca por associar a transgressão às normas e a luta de um povo fez com que a Miss Sergipe tramasse outra imagem desse grupo. No Miss Brasil Gay, Ferrulla Muniz e a miss projetaram a figura de Maria Bonita na luta das mulheres. A biografia de Maria Bonita mostra suas pequenas subversões dentro da própria estrutura machista do cangaço, exemplificando a pretensão de invocar um romantismo e os ícones utópicos de luta política aliados a indumentárias que homogeneízam e idealizam um povo que vive distante desses trajes étnicos no cotidiano (TAYLOR, 2004; NEGREIROS, 2018).

0 viés romântico desse traje étnico aponta para idealizações de elementos do cangaço e das feminilidades que fugiram dessa narrativa sergipana tradicional. Na contramão de parodiar a mulher cangaceira, a Miss Sergipe construiu-se como uma mulher global, da cultura de massa. 0 vestido criou uma silhueta que, entendida como feminina, expandiu o quadril e diminui a barriga, sem qualquer referência a um vestido de cangaceira. 0 salto alto remonta ao feminino e ao frívolo (ROBINSON, 2015). A grande fenda traz um erotismo à concepção final, transformando a miss em um objeto de deleite do outro, em que sua perna hipnotizaria os olhares e criaria uma sedução que brinca de esconder e aparecer (MELLO E SOUZA, 1987). Esse modo de conceber tais trajes étnicos acabam por se repetir nas composições das outras misses, nas quais esses figurinos precisam ser reduzidos a uma imagem do feminino hegemônico e dos traços folclóricos. A partir das informações coletadas, a categoria traje étnico é a que teve menos incidência no concurso.

\section{Trajes globais ou tradicionais?}

Responder à pergunta sobre trajes globais ou tradicionais é compreender o que essas misses querem (a)parecer. Para isso, percorremos os bastidores do traje típico, levando em consideração quem o produziu e como o traje em si vestiu as misses. Engana-se quem pensa que só a miss tem autoridade na construção de sua imagem. Observamos que o estilista teve grande influência na montação exibida, de modo que cada criador tem sua própria assinatura, sendo reconhecida dentro do Miss Brasil Gay. A região do ateliê, seu estilo de vida e a clientela fora da competição ajudam a compor esses trajes.

Muito antes do nosso recorte temporal, em 1992, o coordenador artístico André Pavam reportara ao jornal Tribuna de Minas a importância do Miss Brasil Gay para os estilistas se projetarem nacionalmente, afirmando que dentro do evento haveria um concurso paralelo entre os criadores (TRIBUNA DE MINAS, 1994). Apesar de não ser um evento televisionado, no circuito das competições gays e travestis, ele se estabeleceu como um dos principais concursos de beleza LGBTQ+ no país. Um exemplo interessante é a estilista Michelly X, ganhadora do Miss Brasil Gay 2000 e uma das mais notáveis criadoras da competição. Além 
de produzir figurinos para artistas da televisão, em 2017, ela foi responsável pela criação do national costume da Miss Brasil Monalysa Alcantâra no Miss Universo.

Diferentemente das misses - que podem transitar pelos estados - e do traje típico em si - que define a identidade do ente representado -, os estilistas tomam o caminho contrário, pesquisando e criando sobre o estado dentro daquilo que julgam importante na simbologia disponível no imaginário social, uma síntese cultural de um lugar. Ao analisarmos as formas e os materiais dos trajes, compreendemos que todo o discurso que circunda os estados (econômico, religioso, folclore etc.) não é suficiente na concepção dos trajes típicos. É preciso colocar significados que ultrapassem a ideia de regionalismo, concebendo, assim, contornos para os ideais de glamour, feminilidade e beleza desse grupo com base nos materiais mencionados.

Embora o número de estilistas que produz para o concurso seja diversificado dentro dos trajes típicos pesquisados, atentamo-nos àqueles que mais confeccionaram entre 2017 e 2019 a fim de facilitar as comparações. Os nomes que mais apareceram foram Ribas Azevedo, Luis Leandri, Flavio Rafalski, Michelly X, Ateliê Perfect, Marcelo Dias, Eduardo Marques, Bruna Bee e Ciro Alencar.

Com exceção de Marcelo Dias, Eduardo Marques e Ciro Alencar, os outros estilistas situam-se na região Sudeste, principalmente São Paulo. Outro dado presente é que nem sempre o estado teve um estilista natural do seu território - ou seja, há casos de um ateliê paulista que produziu para uma miss baiana, ou um mineiro que criou para uma miss representante do Maranhão. Ao mesmo tempo, há estilistas que confeccionaram somente para seu estado de origem, como Eduardo Marques e Ciro Alencar, de Pernambuco e Ceará respectivamente.

Ao contrapormos Ribas Azevedo - que produz para estados de regiões diferentes - e Marcelo Dias - que se limitou a representar estados da sua região -, tecemos algumas considerações. Ribas, apesar de maranhense, construiu sua trajetória profissional em São Paulo, criando e confeccionando para o carnaval paulista e para drag queens e transformistas que se apresentam em boates ou concursos de misses. Ele também coordenou eventos de beleza, como o Miss São Paulo Gay em 2018, com Michelly X. Já Marcelo Dias trilhou pelas festividades do Norte do país, como Boi Corre Campo e Concurso de Fantasias e Máscaras do Amazonas, mas também produziu trajes para misses de concursos tradicionais de seu estado.

Ribas Azevedo e Marcelo Dias traçaram diferenças significativas das interpretações sobre as regiões e estados. Ainda que não tenham produzido para os mesmos lugares nesses três anos, ambos tiveram criações que representaram o Norte - e, embora haja diferenças culturais entre os estados (e mesmo diferenças internas no próprio estado), no traje típico a trajetória de cada um fica evidente, não pela distinção étnica, histórica, econômica ou religiosa, mas, sim, pelo imaginário e pelos modos de fazer dos estilistas que permearam as narrativas do Norte.

Esses imaginários são atravessados por diversas tecnologias e discursos no decorrer da vida dos estilistas, compondo o traje típico por meio de uma simbiose entre o ser regional e o ser mulher, posto que a estrutura da roupa teria que esculpir aquilo que é entendido como feminino e transmitir algo que ligue a miss ao estado representado. 
Ribas Azevedo, em uma live intitulada Entre amigos, na sua página do Instagram (@ ribas.azevedo), no dia 20 de junho de 2020, disse que não vestiria uma transformista sem o espartilho, porque as formas femininas - que são as circulares - precisam emergir na montação, algo que o corpo interpretado como masculino não permite. 0 interessante dessa fala não é a negação da materialidade dos corpos, mas a forma como a roupa os transforma em algo, tornando-se um instrumento para modelar as aparências dos gêneros. 0 corpo em si nada mais é do que um corpo, e é na cultura e todo seu aparato estético e político que ele tomará sua inteligibilidade como gênero, seja colocando, tirando, afunilando, aumentando ou diminuindo, é uma criação incessante perpassando por um campo discursivo e material, provocando um deslocamento/rompimento da ordem heterossexual (BONADIO, 2015).

Na imagem abaixo, a Miss Acre de 2017 usou como tema do traje típico uma ave sagrada, o pavão. No entanto, ao se apresentar como uma ave que veioganhado de presente da Ásia no século XVI, destoou de qualquer imagem folclórica do Acre. Ribas pareceu investir em uma narrativa que o possibilitou trabalhar em cima daquilo que ele interpretara como curvas femininas, deixando a questão da cultura acreana em segundo plano, entendendo-a como uma fantasia em geral, na qual ele manipula as referências de feminilidade por meio das peças do traje e do trama livremente fora de uma imagem específica do folclore acreano.

FIGURA 8 - MISS ACRE, CUJO TRAJE REFERE-SE ÀS AVES REAIS (2017)

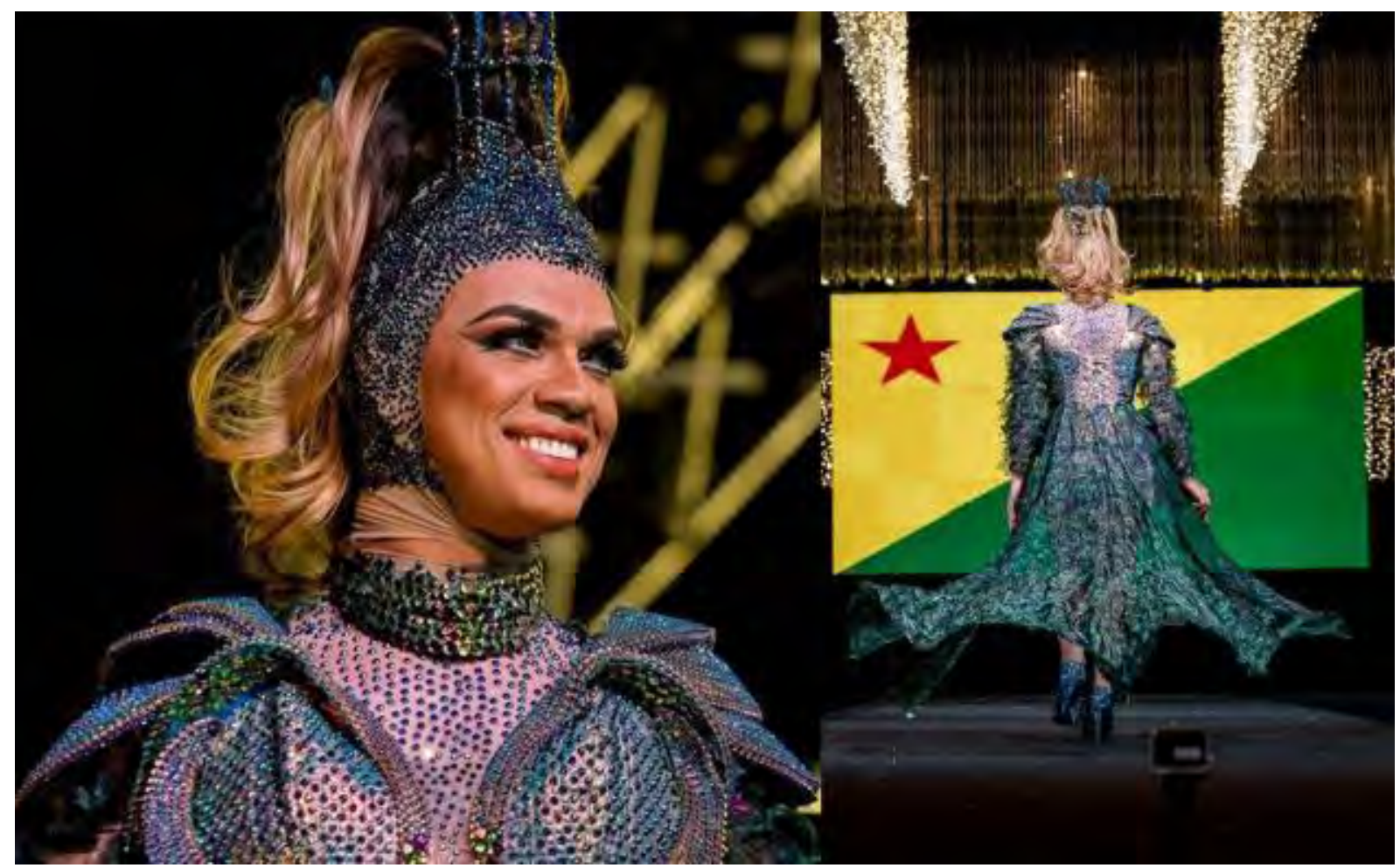

FONTE: Miss Brasil Gay 2017. Juiz de Fora. Miss Brasil Gay, 2017. Foto: Filmar. 
0 traje é bordado em cristais, estampa penas de pavão e uma espaldeira simula um seio farto, além do adereço na cabeça que imita a parte superior da ave. A aparência dessa miss relaciona-se mais às divas pop e aos modelos de espetaculares desfiles de moda do que a alguma imagem que caracterize algum aspecto acreano. 0 traje abrange, desse modo, como as formas de comunicação de massa materializam seus processos ideológicos e, aqui, como as misses e os estilistas modelam feminilidades como forma de participação desse discurso (OCHOA, 2014).

Na criação de Marcelo Dias, em 2018, houve uma associação entre a imagem das festividades amazonenses e o glamour que impera no concurso: as penas do esplendor e o adereço da cabeça projetando uma aparência grandiosa. Com um vestido brilhante e acessórios de penas com grafismos indígenas e vitórias-régias saindo das partes íntimas da miss - recorrendo a um simbolismo de feminilidade ligado aos órgãos genitais considerados femininos, como a vulva e a vagina -, complementados pelo cabelo preto e trançado (diferentemente de muitas misses que usam seus cabelos presos em coques ou com permanentes), a Miss Amazonas se transformou na imagem da lenda indígena brasileira sobre Iara, corroborando também com a ideia de uma sensualidade ligada a corpos racializados.

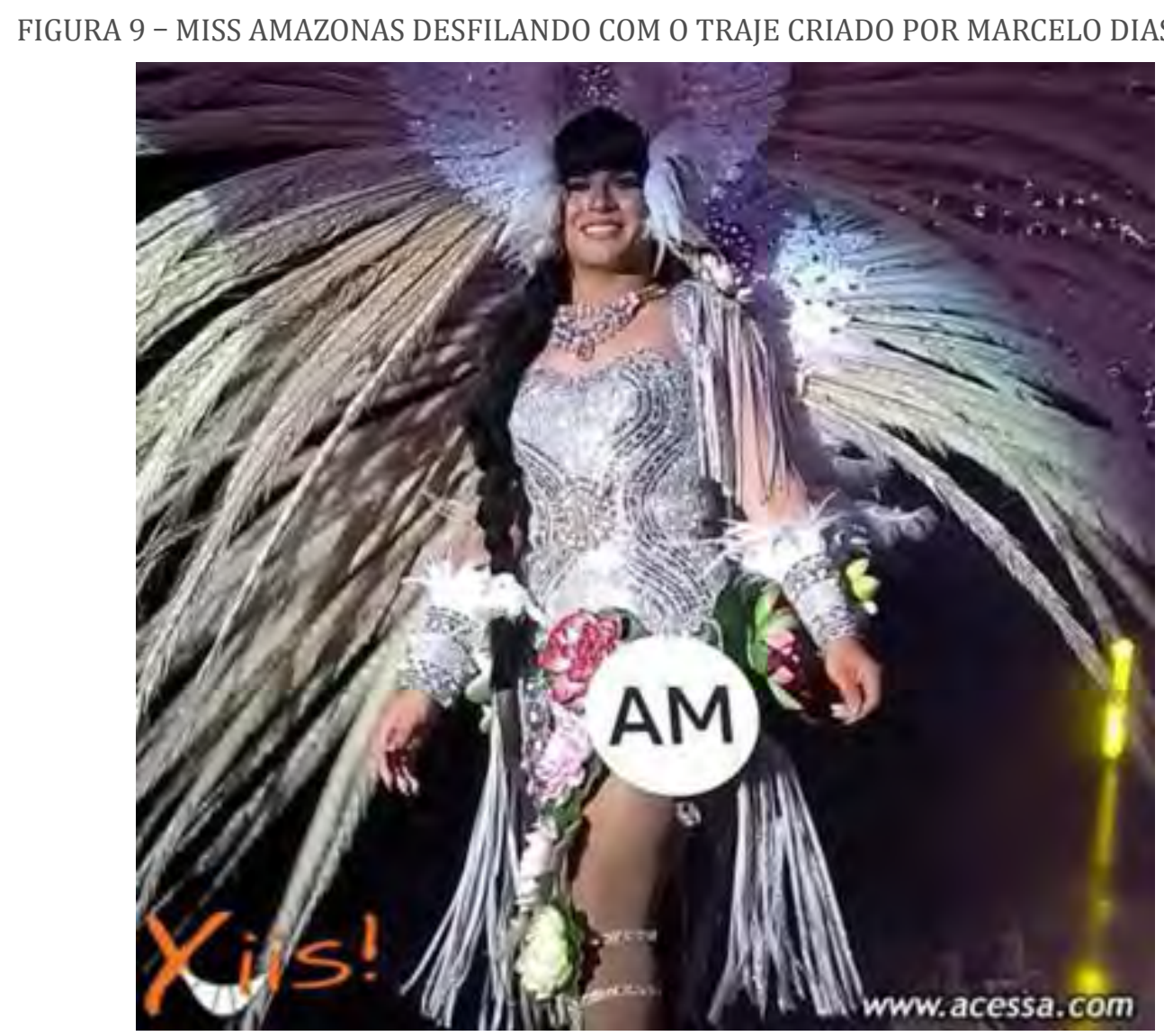

FONTE: Miss Brasil Gay 2018. Xiss. Juiz de Fora: Acessa, 2018. Foto: Acessa.

A feminilidade construída em ambos os trajes típicos é um dos objetivos centrais de um concurso de transformismo (masculino para o feminino). 0 espartilho estava presente tanto na criação de Marcelo Dias quanto na de Ribas Azevedo, entendendo que a forma mais 
afunilada da cintura é vista como uma verdade sobre o corpo da mulher, o que, ao mesmo tempo, denuncia o efeito de diversas tecnologias e discursos, posto que o que esses estilistas reproduzem, na verdade, é o que lhes é transmitido (BUTLER, 2003; DE LAURETIS, 1994).

Marcelo Dias teve a preocupação de abordar a cultura amazonense, e seu cotidiano profissional esteve presente na concepção final. Características étnicas na constituição do traje típico se mostraram importantes paralelamente à preocupação em construir uma aparência feminina. 0 caminho percorrido por Marcelo Dias recai naquilo que já é preestabelecido no imaginário social sobre o Amazonas e a região Norte, com o tradicional/folclórico colocando-se mais importante como marca de determinado espaço, diferenciando-se do moderno, que homogeneíza os lugares e sujeitos. Ribas Azevedo, em contrapartida, assume uma narrativa que parte para o global, deixando como acessórios os aspectos culturais do Acre - se é que, nesse caso, pode-se dizer que houve algum -, arquitetando um traje típico que enalteceria a mulher que se encontra nas principais revistas e nas telas.

Ainda sobre a região Norte, não foi somente Ribas Azevedo que assumiu esse modo de produzir. 0 traje típico construído por Michelly X para a Miss Amapá em 2017, cujo tema eram as minas de diamante, revela pouca importância em relação aos aspectos do estado, que nem se encontra na rota dos maiores produtores da pedra no país. A estilista busca a ideia de uma mulher globalizada para compor suas criações. Michelly X já declarou inspirar-se nos desfiles da Victoria's Secret Fashion Show, e isso reflete profundamente no concurso (SANTOS, 2013).

FIGURA 10 - A MISS AMAPÁ, EM 2017, ENALTECENDO A EXTRAÇÃO DE DIAMANTES COM UMA CRIAÇÃO DE MICHELLY X. AO LADO, EM 2013, A MODELO KARLIE KLOSS, DA MARCA VICTORIA'S SECRET

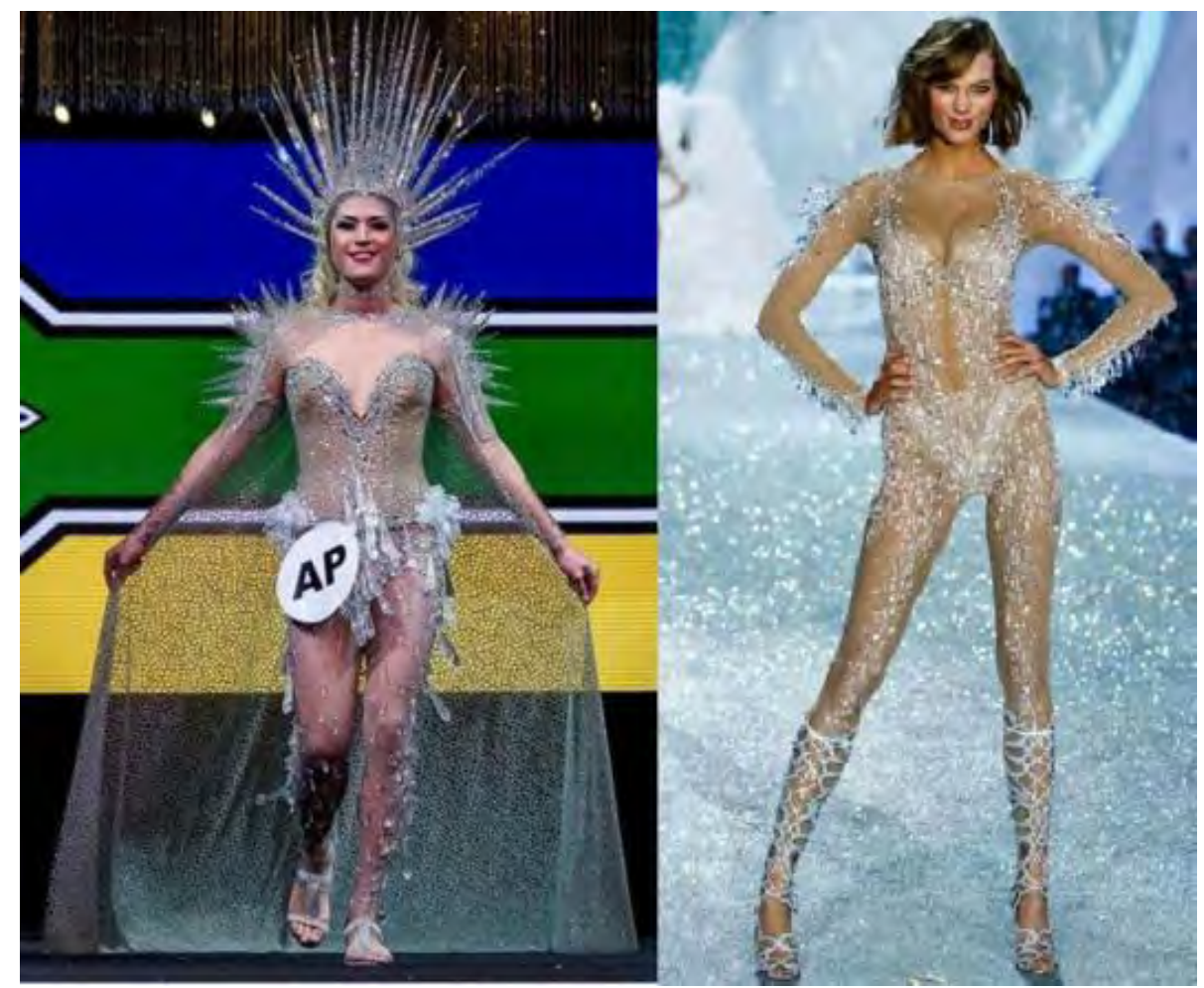

FONTE: Miss Brasil Gay 2017. Juiz de Fora. Miss Brasil Gay, 2017. Foto: Filmar. The Victoria's Secret Fashion Show Fittings - Victoria's Secret Fittings And A Behind The Scenes Look At The Victoria's Secret Model Fittings For The Victoria's Secret Fashion Show. Estados Unidos: Zarzar Models, 2013. 
Com a música Diamonds, da cantora Rihanna, a Miss Amapá desfilou no Miss Brasil Gay seu traje assinado por Michelly X, composto por uma segunda pele cravejada de cristais tchecos e ladrilhos metalizados, uma capa toda reluzente acentuando os quadris e adereços na cabeça que remetem à coroa da Estátua da Liberdade. A cintura também é realçada com simulações de cristais para dar uma forma mais curvilínea ao corpo. Embora toda a performance englobe uma combinação de elementos (traje, música, corpo), a criação de Michelly X aproximou a Miss Amapá da atmosfera de um desfile da marca Victoria's Secret (figura 10). Novamente, os principais traços da cultura amapaense não compuseram a ideia primária de uma representação que se aproxime do já legitimado. A estilista preferiu utilizar imagens de feminilidades globais que compõem aquilo que Louisa Schein (1997, p. 477) entenderia por "cosmopolitismo imaginado", revelando a própria trajetória/subjetividade de Michelly $\mathrm{X}$ como estilista de figurinos midiáticos.

Observamos um cenário em que o sujeito se encontra fragmentado em gênero, sexualidade, etnia e nacionalidade, e isto se dá, como aponta Stuart Hall (2006), porque esses deslocamentos colocam a ideia de identidade em crise. Se antes tínhamos um sujeito essencial, com a problematização dessas aparências percebe-se que a pós-modernidade/globalização oferece um maior trânsito identitário, o agenciamento dessas identidades a possibilidades e narrativas outras, pois “à medida que os sistemas de significação e representação cultural se multiplicam, somos confrontados por uma multiplicidade desconcertante e cambiante de identidades possíveis" (HALL, 2006, p. 13 ).

Nesse sentido, consideramos que a identidade em si é criada e modificada no interior das representações. Não é algo com o qual se nasce, mas que se encontra em disputa no campo dos significados, produzindo sentidos em um sistema de representação cultural (HALL, 2006). Ao nos depararmos com os trajes típicos do Miss Brasil Gay e o modo como eles são concebidos pelos estilistas, interpretamos que as narrativas que compuseram as identidades nem sempre partiram de uma ordem preestabelecida, sedimentada no imaginário social como tradicional, étnico ou folclórico. No concurso, essas questões foram negociadas e atravessadas pela cultura de massa, que as combinou e as contaminou com outras interpretações. Se houve um discurso que deu um verniz natural para a ideia de etnicidade, entendemos que, quando deslocado - e aqui partindo de uma experiência LGBTQ+--, outras percepções sobre os sujeitos puderam ser consideradas.

Conquanto a trajetória profissional fora do concurso do estilista pese e aqueles que se encontram além da região Sudeste muitas vezes tenham tentado escapar de uma globalização do traje típico, buscando enaltecer traços folclóricos de seus estados, observamos que houve sempre vestígios daquilo que consideramos um traço LGBTQ+ mais global nos arranjos dos trajes típicos, como, o uso exagerado de brilho, cristais e strass. Outro ponto é que - com exceção de Marcelo Dias em 2018 - muitas misses e estilistas, ainda que trazendo aspectos étnicos para suas criações, focaram em uma feminilidade global (branca ou euro-estadunidense). 0 que se viu no Miss Brasil Gay como principal foi a emulação de uma mulher da elite, e os ajustes com cintas, corpetes, pirellis (espuma), aquendar (esconder os genitais), maquiagem e perucas nos mostram como certos produtos que constroem a ideia de mulher tiveram maior relevância no concurso, colocando questões folclóricas em segundo plano ou combinando com a construção da feminilidade. 


\section{Considerações finais}

Compreendemos os trajes típicos inseridos em uma inter-relação entre a miss e o estilista. 0 estilista tem o papel de confeccionar e sintetizar aspectos regionais e daquilo que se entende como feminino, colocando seu imaginário e seu modo de fazer no traje final. Embora muitas vezes as reportagens não destaquem seu trabalho, notamos que, dentro do concurso, seus nomes circulam e mostram relevância a partir dos aspectos estilísticos que cada assinatura carrega, promovendo paralelamente uma competição de estilistas que se constroem simbolicamente dentro de concursos transformistas.

Consequentemente, vemos os trajes típicos esculpindo a aparência de uma miss, intermediando não só a percepção dos corpos e suas imagens, como também a nossa percepção do mundo exterior, criando uma experiência particular do sujeito ao usar esse traje típico, transformando-o em uma miss e, igualmente, refletindo-a como tal para a plateia. Desse modo, a miss é interligada ao traje típico, que se estabelece na qualidade de um mediador entre o glamour e a feminilidade transmitidos principalmente pela cultura de massa, pelo qual as misses se experimentam, vivenciam e se constroem mulheres fabulosas, deixando seus cotidianos para trás por um dia.

Na inversão/suspensão do cotidiano, o Miss Brasil Gay traçou um diálogo com o carnavalesco, seja nos aspectos sociais, seja nos estéticos, em que o fazer do carnaval e toda sua aparência reveste o desfile de traje típico com a ideia de camp, que podemos retirar da filósofa Susan Sontag: é o "amor pelo exagerado, pelo off, pelas coisas-sendo-o-que-não-são." (SONTAG, 2020, p. 351 ). Assim, são nesses agenciamentos com brilho, penas, strass e cristais que esses sujeitos foram construindo a ideia de glamour e feminilidade, escapando da coerência heterossexual do feminino do dia a dia e propondo uma feminilidade outra, e não somente exagerada ou não normal, pois soaria uma deslegitimação dessas identidades LGBTQ+. 


\section{Referências}

ABRANTES, Samuel S. Itinerários da criação: abismo; dobra e figurino. Rio de Janeiro: Boaz, 2017.

ANDERSON, Benedict. Comunidades imaginadas: reflexões sobre a origem e a difusão do nacionalismo. São Paulo: Companhia das Letras, 2008.

BAKHTIN, Mikhail M. Cultura popular na Idade Média e no Renascimento: o contexto de François Rabelais. Trad. Yara Frateschi Vieira. 6. ed. São Paulo/Brasília: Hucitec, 2008.

BALOGUN, Oluwakemi M. Cultural and cosmopolitan: idealized femininity and embodied nationalism in Nigerian beauty pageants. Gender \& Society, v. 26, n. 3, 2012, p. 357-381. Disponível em: https://doi.org/10.1177/0891243212438958. Acesso em: 9 nov. 2020.

BARROS, Andréa K. A história da organização homossexual em Juiz de Fora. 2016. 231 f. Tese (Doutorado em Política Social) - Programa de Estudos Pós-Graduados em Política Social da Universidade Federal Fluminense (UFF), Niterói, 2016.

BONADIO, Maria Claudia. O corpo vestido. In: MARQUETTI, Flávia; FUNARI, Pedro Paulo (orgs.). Sobre a pele: imagens e metamorfoses do corpo. 1.ed. São Paulo: Intermeios, 2015, v. 1 , p. $179-206$.

BOURDIEU. Pierre. Questões de sociologia. Rio de Janeiro: Editora Marco Zero Limitada, 1993.

BUTLER, Judith. Problemas de gênero: feminismo e subversão da identidade. Trad. Renato Aguiar. Rio de janeiro: Civilização Brasileira, 2003.

CABALLERO PIZA, Andrés L. The Land of the Most Beautiful Natural Resources Miss Universo: Representaciones de El Dorado y el Traje Típico Colombiano. Revista dObra[s]. v. 11, 2018, p. 22-40.

CALANCA, Daniela. Leis morais e contras. In: História social da moda. São Paulo: Senac, 2008.

DA MATTA, Roberto. Ensaios de antropologia estrutural. Petrópolis: Vozes, 1973.

DE LAURETIS, Teresa. A tecnologia do gênero. In: BUARQUE DE HOLLANDA, Heloisa (org.). Tendências e impasses: 0 feminismo como crítica da cultura. Rio de Janeiro: Rocco, 1994, p. 206-242. 
DYHOUSE, Carol. Glamour: women, history, feminism. London: Zed Books, 2010.

EARLE, Rebecca. Nationalism and national dress in Spanish America. In: ROCES, Mina (ed.). The politics of dress in Asia and the Americas. Brighton: Sussex Academic Press, 2008.

EICHER, Joanne B.; SUMBERG, Barbara. World fashion, ethnic, and national dress. In: EICHER, Joanne B. (edit.). Dress and ethnicity. Change across space and time. Oxford: Berg Editorial, 1999.

ESTRELAS inspiram o Miss Brasil Gay. Tribuna da Tarde. Juiz de Fora, 17 de agosto de 1991, p. 1.

EXÓTICO. Oxford Languages. Oxford: Oxford University Press, 2020.

GIACOMINI, Sônia Maria. A alma da festa: família, etnicidade e projetos num clube social da Zona Norte do Rio de Janeiro: o Renascença Clube. Belo Horizonte: Editora UFMG; Rio de Janeiro: Iuperj, 2006.

GREEN, James N. Além do carnaval: a homossexualidade masculina no Brasil do século XX. São Paulo: Editora UNESP, 2000.

HALL, Stuart. A identidade cultural na pós-modernidade. Rio de Janeiro: DP\&A, 2006.

LOPES, Aureliano. Em desfile nossa terra, nossa gente?: a construção de corporalidades e belezas em concursos femininos diversos. Anais eletrônicos do Seminário Internacional Fazendo Gênero 10,2013. Disponível em: http://www.fazendogenero.ufsc.br/10/resources/ anais/20/1384955923_ARQUIVO_AurelianoLopes.pdf. Acesso em: 9 nov. 2020.

MILLER, Daniel. Trecos, troços e coisas: estudos antropológicos sobre a cultura material. Rio de Janeiro: Editora Zahar, 2013.

MISS BRASIL GAY. Desfile dos trajes típicos do Miss Brasil Gay 2017. 2017. (1h00min09s). Disponível em: https://www.youtube.com/watch?v=h8CMhacjKRk\&t=1906s. Acesso em: 12 mar. 2020.

MULVEY, Laura. Prazer visual e cinema narrativo. In: XAVIER, Ismail (org.). A experiência do cinema: antologia. Rio de Janeiro: Graal, 1983.

NEGREIROS, Adriana. Maria Bonita: sexo, violência e mulheres no cangaço. Rio de Janeiro: Objetiva, 2018. 
NOLETO, Rafael da Silva. "Brilham estrelas de São João!”: notas sobre os concursos de "Miss Caipira Gay" e "Miss Caipira Mix" em Belém (PA). Sexualidad, salud y sociedad, n. 18, dez. 2014, p. 74-110. Disponível em: http://dx.doi.org/10.1590/1984 6487.sess.2014.18.06.a. Acesso em: 8 nov. 2020.

OCHOA, Marcia. Queen for a day. Transformistas, beauty queens, and the performance of femininity in Venezuela. Durham: Duke University Press, 2014.

OLIVEIRA, Madson. A criação dos figurinos carnavalescos para o rancho Ameno Resedá, por meio da análise das aquarelas realizadas por Amaro do Amaral, em 1913. Rio de Janeiro: PPGAV-UFRJ-EBA (Relatório de estágio pós-doutoral), 2014.

ROBINSON, Victoria. Reconceptualising the mundane and the extraordinary: A lens trough which to explore transformation within women's everyday footwear practices. Sociology, v. 49, 2015, p. 903-918.

RODRIGUES, Marcelo C. L'imaginaire de la fête "tribale" au Brésil: l'exemple du "Miss Brésil Gay" à Juiz de Fora. 2014. 351 f. Tese (Doutorado em Sociologia - École Doctorale Sciences Humaines et Sociales, Université Paris Decartes, Paris, 2014.

RODRIGUES, Marcelo C. Miss Brasil Gay, polêmica na passarela: eventos como instrumento de comunicação alternativa. 2008. 148 f. Dissertação (Mestrado em Comunicação Social) - Programa de Pós-Graduação em Comunicação da Universidade de Juiz de Fora, Juiz de Fora, 2008.

SANTOS, Eliane. Conheça Michelly X: nova estilista queridinha das famosas no samba. Ego. Disponível em: http://ego.globo.com/carnaval/2013/noticia/2013/01/conheca-michellyxis-nova-estilista-queridinha-das-famosas-no-samba.html. Acesso: 21 jan. 2019.

SCHEIN, Louisa. The consumption of color and the politics of white skin in post-Mao China. In: LANCASTER, Roger; DI LEONARDO, Micaela (eds.). The gender/sexuality reader: Culture, history, political economy. New York: Routledge, 1997.

SCOTT, Joan W. Gênero: uma categoria útil de análise histórica. Educação \& Realidade. Porto Alegre, v. 20, n. 2, jul./dez. 1995.

SOLIVA, Thiago B. Sob o símbolo do glamour: um estudo sobre homossexualidades, resistência e mudança social. 2016. 250 f. Tese (Doutorado em Antropologia Cultural) Programa de Pós-Graduação em Sociologia e Antropologia da Universidade Federal do Rio de Janeiro, Rio de Janeiro. 2016. 
SONTAG, Susan. Notas sobre o “camp”. In: SONTAG, Susan. Contra a interpretação: e outros ensaios. Trad. Denise Bottmann. São Paulo: Companhia das Letras, 2020.

SOUZA, Gilda de M. O espírito das roupas: a moda no século dezenove. São Paulo, Companhia das Letras, 1987.

TAYLOR, Lou. Ethnographical approaches. In: TAYLOR, Lou. The study of dress history. Manchester: Manchester University Press, 2004.

TRANSFORMISTAS disputam hoje o 18ํㅡㄹ Miss Gay. Tribuna de Minas. Juiz de Fora, 20 de agosto de 1994, p. 2.

VEBLEN, Thorstein. A teoria da classe ociosa: um estudo econômico das instituições. Trad. Olívia Krähenbühl. São Paulo: Ática, 1974.

VIANA, Fausto. 0 traje como objeto disparador da memória: o caso de A garota dinamarquesa. In: VIANA, Fausto; MOURA, Carolina B. (orgs.). Dos bastidores eu vejo o mundo. São Paulo: ECA/USP, 2017. 